\title{
Peran Kepuasan Sebagai Mediator Kualitas Produk Pada Niat Beli Ulang (Studi Pengguna Sepeda Motor Yamaha Mio di Kabupaten Karanganyar)
}

\author{
Aji Yudha, Lela Lestari \\ Universitas Diponegoro \\ ajiyudha@lecturer.undip.ac.id
}

\begin{abstract}
Abstrak
Beberapa penelitian sebelumnya mengkaji korelasi antara variabel kualitas produk, perceived value, kepuasan dan pengaruhnya pada niat beli ulang. Namun tidak ada konsistensi hasil diantara hasil penelitian sebelumnya. Lalu, adanya fenomena penurunan penjualan produk Sepeda Motor Yamaha Mio sehingga perlu dilakukan penelitian ini. Sejumlah 140 masyarakat berpartisipasi pada penelitian ini. Hasil penelitian menunjukkan bahwa kualitas produk mengarah pada kepuasan dan pada akhirnya membuat konsumen untuk berniat melakukan pembelian ulang. Namun, penelitian ini memiliki keterbatasan berupa sedikitnya jumlah responden dan hanya berada di satu daerah. Penelitian selanjutnya diharapkan menambah jumlah responden dan menambahkan variabel lain supaya mendapatkan model penelitian yang lebih komprehensif dan hasil yang bisa digeneralisir.
\end{abstract}

Kata kunci: kualitas produk, perceived value, kepuasan, niat beli ulang

\begin{abstract}
Several previous studies examined the variables of product quality, perceived value, satisfaction, and their effect on repurchase intention. However, there is no consistency of results among the results of previous studies. Then, the phenomenon of the decline in the sales value of Yamaha Mio Motorcycle products, so this research is necessary. The number of 140 people in this study. The results showed that product quality leads to satisfaction and ultimately leads consumers to repurchase. However, this study has limitations in the form of the number of respondents and is only in one area. Future research is expected to increase the number of respondents and add other variables to provide a more complete research model and generalizable results.
\end{abstract}

Keywords : product quality, perceived value, satisfaction, repurchase intention

\section{PENDAHULUAN}

Memahami perilaku niat beli ulang oleh konsumen akan memudahkan peneliti dan praktisi dalam mengembangkan model pemikiran dan strategi yang tepat. Niat konsumen dalam pembelian ulang adalah salah satu bentuk loyalitas konsumen kepada suatu brand yang baik untuk jangka panjang. Kotler (2009) menjelaskan bahwa niat untuk membeli ulang dapat diciptakan melalui kepuasan dan perceived value (nilai yang dirasakan oleh konsumen). Kepuasan adalah perasaan yang dialami oleh konsumen saat membandingkan persepsi hasil produk terhadap persepsi mereka (Kotler, 2009).

Kepuasan juga menjadi prediktor yang sangat kuat ketika dihubungkan dengan niat membeli ulang (Dölarslan, 2014). Artinya, apabila konsumen merasa puas maka ada kecenderungan akan membeli kembali produk tersebut. Namun apabila produk tersebut tidak sebanding dengan harapan, maka konsumen akan meninggalkan produk tersebut.

Kepuasan muncul disebabkan oleh beberapa faktor yang mempengaruhi. Karena kepuasan 
muncul dari persepsi konsumen maka faktor yang mempengaruhi adalah perceived value (penilaian konsumen). Perceived value merupakan perbandingan manfaat yang dirasakan konsumen saat membeli produk atau jasa dibanding biaya saat membeli produk atau jasa tersebut.

Yang (2018) dalam temuannya menjelaskan bahwa pengaruh perceived value sangat kuat pada kepuasan. Konsumen akan menimbang antara manfaat produk dengan biaya yang dikeluarkan. Apabila produk tersebut memiliki lebih banyak manfaat dibandingkan dengan harga yang dibayar, maka perceived value konsumen akan tinggi yang pada akhirnya akan meningkatkan kepuasan terhadap produk tersebut. Namun sebaliknya, apabila manfaat yang dirasakan kurang daripada harga yang dibayar, maka perceived value konsumen akan rendah yang kemudian mengurangi kepuasan konsumen akan produk tersebut.

Perceived value dapat dipengaruhi oleh kualitas produk. Hal ini karena untuk menciptakan perceived value, konsumen harus merasakan produk tersebut. Semakin berkualitas produk tersebut, maka semakin baik pula perceived value konsumen yang pada akhirnya akan mempengaruhi kepuasan. Hasil penelitian yang dilakukan oleh Gök et al., (2019) mengemukakan bahwa kualitas produk yang baik akan menambah nilai suatu produk, meningkatkan diferensiasi produk, dan secara positif mendukung penilaian kualitas produk oleh konsumen.

Apabila kualitas produk tersebut baik maka value yang dirasakan oleh konsumen tersebut akan tinggi dan juga meningkatkan kepuasan konsumen akan produk tersebut. Namun apabila kualitas produk tersebut buruk maka konsumen akan menilai value produk akan rendah dan secara langsung konsumen tidak puas terhadap produk tersebut.

Namun, beberapa penelitian sebelumnya mengemukakan hasil yang berbeda. Bei \& Chiao (2006) mengemukakan tidak ada pengaruh antara kualitas produk dengan kepuasan. Hal ini berbeda dengan yang dikemukakan oleh Gök et al., (2019) dimana kualitas produk sangat mempengaruhi tingkat kepuasan konsumen.

Hasil penelitian yang dilakukan oleh Ajami et al., (2018) tidak ada hubungan antara kualitas produk dengan perceived value. Namun Alex \&
Thomas (2011) menjelaskan ada pengaruh positif antara kualitas produk dan perceived value.

Hasil penelitian yang dilakukan oleh (Shih \& Fang (2005) mengemukakan bahwa kepuasan berdampak tidak terlalu signifikan pada niat beli ulang. Namun Curtis et al., (2011) mengemukakan kepuasan sangat mempengaruhi niat membeli ulang. Adanya gap antara hasil penelitian lain menjadikan dasar penelitian ini dilakukan.

Obyek penelitian ini pada pengguna sepeda motor Yamaha Mio. Pemilihan ini didasarkan pada masih sedikitnya literatur yang membahas niat beli ulang pada produk kategori high involvement decision making yang berarti konsumen membutuhkan serangkaian proses berpikir yang matang sebelum memutuskan membeli produk tesebut. Pemilihan jenis skuter matik Yamaha Mio dipilih berdasarkan data masyarakat Indonesia lebih menyukai sepeda motor jenis skuter matik. Asosiasi Industri Sepeda Motor Indonesia (AISI) menunjukkan angka penjualan Sepeda Motor Yamaha Mio yang fluktuatif sepanjang tahun 2015 - 2019 yang disajikan pada table berikut:

Tabel 1. Jumlah Pertumbuhan Sepeda Motor Yamaha di Indonesia Tahun 2015 - 2019

\begin{tabular}{ll}
\hline Tahun & Penjualan \\
\hline 2019 & 1.434 .217 \\
\hline 2018 & 1.455 .088 \\
\hline 2017 & 1.348 .211 \\
\hline 2016 & 1.394 .078 \\
\hline 2015 & 1.798 .630 \\
\hline \multicolumn{2}{l}{ Sumber: AISI, 2020}
\end{tabular}

Data tersebut menunjukkan bahwa penjualan sepeda motor Yamaha di Indonesia berfluktuasi dengan tren menunjukkan penurunan. Hal ini menjadi permasalahan bagaimana meningkatkan penjualan Sepeda Motor Yamaha Mio oleh masyarakat dengan memunculkan niat beli ulang. Penelitian ini dilakukan berdasarkan adanya reseach gap dan fenomena gap tersebut.

\section{Kualitas Produk}

Lee \& Tai (2009) mengemukakan kualitas produk pada industri otomotif dapat ditentukan oleh benefit pada produk tersebut dan image dari produk tersebut. Berdasarkan pernyataan dari Ravald \& Grönroos, (1996) menunjukkan bahwa value dapat dipengaruhi oleh kualitas produk. 
Nilai merupakan manfaat baik berwujud atau tidak berwujud yang berupa kombinasi dari kualitas, harga, dan pelayanan. Nilai akan meningkat apabila kualitas juga meningkat dan menurun apabila kualitas juga menurun (Kotler, 2009).

Penelitian Alex \& Thomas (2011) mendukung pernyataan tersebut dimana adanya korelasi positif antara kualitas produk dengan perceived value konsumen. Beneke et al., (2013) mengemukakan adanya hubungan positif dan signifikan antara kualitas produk dan perceived value. Han \& Kwon (2009) menjelaskan kualitas produk yang dirasakan konsumen akan berdampak positif pada perceived value. Hasil penelitian yang dilakukan oleh Beneke et al., (2015) Perceived value dapat dimunculkan dengan kualitas produk yang baik. Vera (2015) mengemukakan bahwa kualitas menjadi pendorong penting dalam perceived value konsumen.

Apabila kualitas produk ini baik akan meningkatkan kepuasan dan perceived value dari konsumen. Berdasarkan pemaparan diatas diajukan hipotesis yaitu:

$\mathrm{H} 1$ : Kualitas produk berpengaruh pada perceived value

Hasil penelitian lain menujukkan bagaimana kualitas produk mempengaruhi kepuasan. Gök et al., (2019) mengemukakan bahwa kualitas produk berpengaruh positif terhadap kepuasan konsumen. Hasil penelitian yang sama dikemukakan oleh Asgharian et al., (2010) bahwa kualitas produk berpengaruh pada kepuasan konsumen. Chumpitaz \& Paparoidamis, (2020) mengemukakan kepuasan dapaat timbul dari kualitas produk yang baik. Salahuddin \& Lee, (2020) konsumen yang senang salah satunya karena kualias produk yang baik. Johnson et al., (2007) mengemukakan hal yang sama semakin konsumen puas dapat disebabkan oleh kualitas yang baik.

Berdasarkan pemaparan diatas diajukan hipotesis yaitu:

H2: Kualitas produk berpengaruh pada kepuasan

\section{Perceived Value}

Konsumen yang menggunakan produk akan menimbang antara manfaat yang dirasakan dengan uang yang mereka bayarkan disebut
Customer Perceived Value (CPV). Kotler (2009) menjelaskan memberikan nilai yang maksimal akan mengarahkan pada kesetiaan konsumen. Perusahaan mengajukan proporsi nilai kepada konsumen dalam menjalankan bisnisnya. Proporsi nilai berupa keuntungan untuk memenuhi kebutuhan konsumen. Penawaran ini akan berhasil apabila memberikan nilai dan kepuasan. Menurut Ravald \& Grönroos, (1996) nilai dapat diciptakan dengan beberapa cara yaitu:

1. Meningkatkan benefit

Meningkatkan benefit berarti menambahkan suatu nilai pada produk tersebut yang dirasa penting, menguntungkan, dan unik bagi konsumen. Memberikan produk yang berkualitas dan pelayanan yang memuaskan akan meningkatkan value pada produk tersebut

2. Mengurangi keengganan konsumen untuk membeli

Cara ini dapat dilakukan dengan mengurangi harga barang, dan meningkatkan kenyamanan saat berbelanja.

Apabila konsumen merasakan manfaat yang dirasakan lebih besar akan mengarah pada kepuasan membeli produk.

Pernyataan tesebut sesuai dengan hasil penelitian Yang, (2018) yang menjelaskan ada korelasi positif yang kuat perceived value mempengaruhi niat beli ulang. Anwar \& Gulzar, (2011) mengemukakan hubungan positif dan signifikan pada perceived value dan kepuasan. Hasil penelitian yang dikemukakan oleh Raza \& Siddiquei, (2012) mengemukakan bahwa perceived value berpengaruh positif pada kepuasan. Md. Ariff et al., (2012) mengemukakan bahwa perceived value (baik ekonomi, emosional, maupun social) berhubungan positif dengan kepuasan. Lai \& Chen, (2011) berpendapat kepuasan akan diperoleh dengan memberikan nilai yang terbaik.

Berdasarkan pemaparan diatas diajukan hipotesis yaitu:

H3: Perceived value berpengaruh pada Kepuasan

\section{Kepuasan}

Konsumen akan puas manakala hasil yang didapat sesuai dengan apa yang dipikirkan (Kotler, 2009). Kesetiaan konsumen, 
menyebarkan berita baik tentang produk suatu brand adalah hasil dari kepuasan yang dirasakan. Metode pengiriman produk, keandalan produk atau jasa, image perusahaan / produk / brand, perceived value, kinerja karyawan, dan keunggulan kompetitif perusahaan dapat mempengaruhi kepuasan (Cravens, 1996). Apabila konsumen puas maka ada kemungkinan untuk berniat melakukan pembelian ulang. Kepuasan diukur dengan tiga indikator yaitu: rasa suka, harapan terpenuhi, dan tidak pernah mengecewakam konsumen.

Pemikiran tersebut didukung oleh hasil penelitian terdahulu dimana niat beli ulang dipengaruhi oleh kepuasan yang tinggi Dölarslan, (2014). Curtis et al., (2011) mengemukakan bahwa semakin puas konsumen pada suatu produk maka ada dorongan niat untuk membeli lagi. Anwar \& Gulzar (2011) dalam temuannya mengemukakan niat beli ulang sangat dipengaruhi oleh kepuasan. Chang et al., (2014) mengemukakan bahwa terdapat korelasi positif antara kepuasan dan niat beli ulang. Trivedi \& Yadav, (2018) mengemukakan bahwa kepuasan secara positif mempengaruhi niat beli ulang.

Berdasarkan pemaparan diatas maka hipotesis yang diajukan adalah:

\section{H4: Kepuasan berpengaruh pada niat beli ulang}

\section{Niat Beli Ulang}

Niat beli ulang adalah tahapan dalam strategi perusahaan membangun hubungan jangka panjang dengan konsumen. Tahapan ini disebut dengan relationship value, yaitu dengan meningkatkan benefit bagi konsumen lalu merangsang aktivitas niat beli kemudian menjaga hubungan dengan konsumen. Ketika hubungan sudah terjalin maka akan memunculkan kredibilitas brand dan kepercayaan yang pada akhirnya mengarah pada loyalitas Ravald \& Grönroos (1996).

Beberapa penelitian telah menjelaskan bagaimana niat beli ulang bisa terbentuk. Dölarslan (2014) mengemukakan bahwa kepuasan konsumen dan perceived value mempengaruhi niat beli ulang. Gök et al., (2019) mengemukakan bahwa kualitas suatu produk akan mempengaruhi kepuasan dimana Chang et al., (2014) mengemukakan bahwa kepuasan pada konsumen dapat memicu niat beli ulang.

\section{METODE}

\section{Jenis dan Sumber Data}

Jenis penelitian yang dilakukan adalah penelitian kausal yaitu menunjukkan arah hubungan variable bebas (independen) dengan variable terikat (dependen). Sebanyak 140 responden masyarakat pengguna Sepeda Motor Yamaha Mio di Kabupaten Karanganyar berpartisipasi pada penelitian ini dengan mengisi kuisioner secara online atau secara fisik.

\section{Metode Analisis Data}

Uji validitas dan reliabilitas digunakan sebelum mengukur hubungan antar hipotesis. Uji validitas digunakan untuk mengetahui ketepatan pertanyaan yang diajukan. Pertanyaan yang tepat apabila dapat mengungkapkan variabel yang sedagn diukur.

Reliabilitas digunakan untuk mengukur kuisioner bebas dari kesalahan atau tidak. Menurut Sekaran (2006) pengukuran reliabilitas, digunakan analisis Cronbach Alpha dimana koefisien alpha dikategorikan diantaranya:

1. $0.8-1.0=$ reliabilitas baik

2. $0.6-0.799=$ reliabilitas dapat diterima

3. $<0.6=$ reliabilitas kurang baik

\section{Pengujian Model}

\section{Measure of fit Structural Model}

Pengukuran goodness of fit structural model pada penelitian ini menggunakan FIT dan AFIT. FIT menunjukkan variasi total dari semua variabel yang digunakan pada model penelitian, setara Rsquare pada regresi. Sedangkan, AFIT (Adjusted FIT) menunjukkan perbandingan model. Semakin tinggi nilai AFIT menunjukkan model yang paling baik.

\section{Measure of fit Overall}

Menunjukkan penilaian model keseluruhan yang digunakan pada GeSCA. Berikut disajikan kriteria goodness of fit dan nilai cut off beserta nilai SRMR:

\begin{tabular}{|c|c|}
\hline $\begin{array}{c}\text { Goodness of } \\
\text { Fit }\end{array}$ & $\begin{array}{l}\text { Cut } \\
\text { Off }\end{array}$ \\
\hline SRMR & $\leq 0,08$ \\
\hline GFI & $\geq 0,90$ \\
\hline \multicolumn{2}{|c|}{ Sumber: sem-gesca.org } \\
\hline \multicolumn{2}{|c|}{ Tabel 3 Kriteria SRMR } \\
\hline SRMR & Keteran \\
\hline
\end{tabular}




\begin{tabular}{cl}
\hline$<0,05$ & Model sangat sesuai \\
\hline $0,05-0,08$ & Model sesuai \\
\hline $0,08-0,1$ & Model cukup sesuai \\
\hline$>0,1$ & Model tidak sesuai \\
\hline \multicolumn{2}{c}{ Sumber: sem-gesca.org }
\end{tabular}

\section{Pengujian Hipotesis}

Penelitian ini menggunakana metode resampling bootstrap supaya independensi antar data yang dianalisis akan terjamin dengan metode ini. Sehingga nonprobability sampling dapat diakomodir dengan metode ini

Penelitian ini menggunakan nilai perbandingan antara critical ratio (C.R) dengan $Z$ value untuk menguji hipotesis. Kriteria $\mathrm{Z}$ value sebagai berikut:

\begin{tabular}{cc}
\multicolumn{2}{c}{ Tabel 4 Z Value } \\
\hline Signifikan & C.R \\
\hline $1 \%$ & $\geq 2,56$ \\
\hline $5 \%$ & $\geq 1,96$ \\
\hline $10 \%$ & $\geq 1,54$ \\
\hline
\end{tabular}

Sumber: http://www.spss.com/amos

Penelitian ini menggunakan signifikansi $5 \%$, sehingga hipotesis akan ditolak apabila tidak memenuhi taraf signifikansi.

\section{Pengujian Efek Mediasi}

Pengujian menggunakan Sobel Test yang dilakukan dengan menghitung pembagian koefisien pengaruh tidak langsung dengan standar error. Sobel Test menggunakan rumus berikut:

z_value $=(\mathrm{a} \times \mathrm{b}) / \mathrm{SQRT}(\mathrm{b} 2 \times \mathrm{SEa} 2+\mathrm{a} 2 \times \mathrm{SEb} 2)$

Keterangan:

$\mathrm{a}=$ koefisien regresi standardized pengaruh variabel penjelas $\mathrm{X}$ terhadap variabel mediasi $\mathrm{M}$ $\mathrm{SEa}=$ standard error untuk koefisien $\mathrm{a}$.

$\mathrm{B}=$ koefisien regresi standardized pengaruh variabel moediasi terhadap variabel dependen $\mathrm{Y}$. $\mathrm{SEb}=$ standard error untuk koefisien $b$

Apabila z-value $>1,96$ atau tingkat signifikansi statistik z (p-value) $<0,05$, menunjukkan pada taraf signifikansi 0,05 dan dapat disimpulkan ada pengaruh tidak langsung antara variabel independen terhadap dependen melalui variabel mediasi.

HASIL

\section{Uji Validitas dan Reliabilitas}

Hasil uji validitas suatu instrumen pertanyaan yang digunakan sebagai dapat dilihat pada tabel berikut:

Tabel 5 Hasil Uji Validitas

\begin{tabular}{|c|c|c|c|c|}
\hline & \multicolumn{4}{|c|}{ Component } \\
\hline & 1 & 2 & 3 & 4 \\
\hline NBI1 & & 0,891 & & \\
\hline $\mathrm{NBI} 2$ & & 0,861 & & \\
\hline NBI3 & & 0,857 & & \\
\hline KP1 & & & & 0,580 \\
\hline KP2 & & & & 0,779 \\
\hline KP3 & & & & 0,781 \\
\hline PV1 & 0,831 & & & \\
\hline PV2 & 0,883 & & & \\
\hline PV3 & 0,907 & & & \\
\hline KP1 & & & 0,584 & \\
\hline KP2 & & & 0,825 & \\
\hline KP3 & & & 0,736 & \\
\hline KP4 & & & 0,710 & \\
\hline
\end{tabular}

Hasil uji validitas sebanyak 140 responden menunjukkan semua indkator terekstrak dengan baik dan valid.

Sedangkan hasil uji reliabilitas sebagai berikut:

Tabel 6 Uji Reliabilitas

\begin{tabular}{lc}
\hline \multicolumn{1}{c}{ Variabel } & Cronbach's Alpha \\
\hline Niat Beli Ulang & 0,870 \\
Kepuasan Konsumen & 0,710 \\
Perceived Value & 0,889 \\
Kualitas Produk & 0,789 \\
\hline
\end{tabular}

Sumber: SPSS

Hasil pengujian reliabilitas menunjukkan bahwa seluruh variabel penelitian bernilai diatas 0,60 sehingga dinyatakan reliabel.

\section{Uji Model}

Berikut disajikan hasil pengujian model penelitian pada table berikut:

Tabel 7 Hasil Measurement of Fit Model

\begin{tabular}{lll}
$\begin{array}{l}\text { Goodness of fit } \\
\text { indicates }\end{array}$ & Hasil & Keterangan \\
\hline FIT & 0,585 & Baik \\
\hline AFIT & 0,578 & Baik \\
\hline GFI & 0,992 & Baik \\
\hline SRMR & 0,071 & Sesuai \\
\hline
\end{tabular}




\begin{tabular}{ccc}
\hline NPAR & 30 & Baik \\
\hline & Sumber: Data primer yang diolah
\end{tabular}

Penelitian ini menunjukkan nilai FIT yan baru. Nilai FIT menunjukkan 0,485 yang berarti variabel kualitas produk, perceived value, kepuasan dan nuat beli ulang mampu menjelaskan 58,5\% sedangkan $41,5 \%$ dijelaskan variabel di luar penelitian. Nilai AFIT juga menunjukkan model penelitian yang baik. Nilai AFIT menunjukkan 0,578 yang berarti kualitas produk, perceived value, kepuasan, niat beli ulang dijelaskan $57,8 \%$ dan $42,2 \%$ sisanya dijelaskan variabel di luar penelitian.

Nilai GFI menunjukkan semakin baik tidaknya suatu model, apabila nilai GFI mendekati 1 maka model dikatakan baik. Nilai GFI sebesar 0,992 artinya mendekati 1 maka dapat disimpulkan model semakin baik. Nilai SRMR dikatakan sesuai apabila mendekati 0 , sehingga model penelitian ini dapat dikatakan sesuai karena nilainya sebesar 0,071 . Sehingga apabila dilihat secara keseluruhan model penelitian ini bisa diterima.

\section{Uji Hipotesis}

Hasil pengujian hipotesis yang dilakukan pada penelitian ini ditampilkan pada tablel berikut:

Tabel 8 Regression Weight

\begin{tabular}{lccc}
\hline \multicolumn{3}{c}{ Path Coefficients } \\
\hline & Estimate & SE & CR \\
\hline $\mathrm{KP}>\mathrm{PV}$ & 0,447 & 0,093 & $4,79^{*}$ \\
\hline $\mathrm{KP}>\mathrm{KS}$ & 0,535 & 0,097 & $5,52^{*}$ \\
\hline $\mathrm{PV}>\mathrm{KS}$ & 0,152 & 0,100 & 1,53 \\
\hline $\mathrm{KS}>\mathrm{NBI}$ & 0,386 & 0,076 & $5,1^{*}$ \\
\hline
\end{tabular}

$\mathrm{CR}^{*}=$ significant at .05 level

$\mathrm{KP}=$ Kualitas Produk, $\mathrm{PV}=$ Perceived Value, $\mathrm{KS}=$ Kepuasan, NBI = Niat Beli Ulang

Sumber: GeSCA

Hasil pengujian hipotesis pada penelitian ini sebagai berikut:

\section{Uji Hipotesis 1}

Sesuai dengan hasil penelitian yang disajikan pada tabel 8 menunjukkan nilai Critical Ratio hubungan kualitas produk pada perceived value sebesar 4,79 yang berarti nilai tersebut diatas yang dipersyaratkan sebesar 1,96 atau pada tingkat signifikansi sebesar $5 \%$ serta bernilai positif. Oleh karena itu hipotesis kualitas produk berpengaruh terhadap perceived value diterima.

\section{Uji Hipotesis 2}

Sesuai dengan hasil penelitian yang disajikan pada tabel 8 menunjukkan nilai Critical Ratio hubungan kualitas produk pada kepuasan sebesar 5,52 yang berarti nilai tersebut diatas yang dipersyaratkan sebesar 1,96 atau pada tingkat signifikansi sebesar $5 \%$ serta bernilai positif. Oleh karena itu hipotesis kualitas produk berpengaruh terhadap kepuasan diterima..

\section{Uji Hipotesis 3}

Sesuai dengan hasil penelitian yang disajikan pada tabel 8 menunjukkan nilai Critical Ratio hubungan perceived value pada kepuasan sebesar 1,53 yang berarti nilai tersebut dibawah yang dipersyaratkan sebesar 1,96 atau pada tingkat signifikansi 5\%. Sehingga, hipotesis perceived value berpengaruh terhadap kepuasan tidak diterima.

\section{Uji Hipotesis 4}

Sesuai dengan hasil penelitian yang disajikan pada table 8 menunjukkan nilai Critical Ratio hubungan kepuasan pada niat beli ulang sebesar 5,1 yang berarti nilai tersebut diatas yang dipersyaratkan sebesar 1,96 atau pada tingkat signifikansi sebesar $5 \%$ serta bernilai positif. Oleh karena itu hipotesis kepuasan berpengaruh terhadap niat beli ulang.

\section{Uji Mediasi}

Hasil pengujian mediasi menggunakan Sobel Test didapat nilai z sebesar $3,736(>1,96)$ dengan tingkat signifikansi 0,0002 ( $p$ value $<0,05$ ). Berdasarkan uji mediasi tersebut kepuasan memediasi secara parsial hubungan antara kualitas produk pada niat beli ulang.

\section{Pembahasan}

Penelitian bertujuan memahami pengaruh vaariabel kualitas produk, perceived value, kepuasan pada niat beli ulang. Dari hasil penelitian yang dilakukan didapatkan hasil sebagai berikut. Perceived value terbukti dipengaruhi oleh kualitas produk. Hasil ini menunjukkan konsumen dapat merasakan manfaat melalui kualitas produk yang baik dari Yamaha Mio. Apabila kualitas produk semakin baik, konsumen akan semakin merasakan 
manfaatnya. Sebaliknya kualitas produk yang menurun konsumen akan merasakan manfaat yang kurang. Hal ini sesuai dengan yang diutarakan oleh Beneke et al., (2015) \& Vera (2015) perceived value sangat dipengaruhi oleh kualitas produk

Selain itu, kualitas produk juga mempengaruhi kepuasan. Artinya konsumen akan semakin puas apabila kualitas produk Yamaha Mio yang ditawarkan semakin baik. Sebaliknya, kualitas produk yang tidak baik justru akan mengurangi kepuasan konsumen. Hasil penelitian ini sesuai dengan yang diutarakan oleh Chumpitaz \& Paparoidamis (2020) dan Salahuddin \& Lee (2020) dimana kualitas produk yang baik akan menumbuhkan kepuasan bagi konsumen.

Hasil penelitian ini mengungkapkan bahwa perceived value tidak mempengaruhi kepuasan konsumen. Karakter konsumen yang berbeda pada Yamaha Mio menyebabkan adanya factor lain yang membentuk perceived value seperti Corporate Image. Konsumen dapat memahami persepsi yang positif berdasarkan Corporate Image yang baik. Selain itu, persepsi harga juga dapat berpengaruh pada niat pembelian Yamaha Mio. Perilaku pembelian konsumen akan tercipta dari kualitas produk yang baik dan persepsi harga yang sesuai dengan konsumen. Oleh karena itu, apabila persepsi harga sesuai dengan kualitas produk, ada kemungkinan konsumen akan berniat membeli ulang sepeda motor Yamaha Mio. Hasil penelitian ini tidak sesuai dengan hasil penelitian oleh Md. Ariff et al., (2012) dan Raza \& Siddiquei (2012) yang menyatakan bahwa perceived value mempengaruhi kepuasan. Sehingga konsumen berniat membeli ulang Yamaha Mio karena didasarkan puas akan kualitas produk.

Hasil penelitian ini mengungkapkan bahwa adanya korelasi positif antara kepuasan dengan niat beli ulang. Konsumen yang puas akan berniat membeli Yamaha Mio. Hasil penelitian ini sesuai dengan yang disampaikan oleh Dölarslan (2014) dan Chang et al., (2014) dimana konsumen yang semakin puas akan meningkatkan niat untuk membeli ulang.

\section{KESIMPULAN DAN SARAN}

Penelitian ini menguji pengaruh kualitas produk, perceived value, kepuasan dan niat beli ulang. Berdasarkan hasil pengujian yang telah dilakukan didapatkan hasil sebagai berikut:

1. Variabel kualitas produk mempengaruhi perceived value secara positif dan signifikan.

2. Variabel kualitas produk mempengaruhi kepuasan secara positif dan signifikan.

3. Variabel perceived value tidak mempengaruhi kepuasan.

4. Variabel kepuasan mempengaruhi niat beli ulang secara positif dan signifikan.

5. Variabel kualitas produk secara tidak langsung mempengaruhi niat beli ulang melalui kepuasan.

Hasil penelitian ini berkontribusi pemahaman hubungan antar variable pada produk high involvement decision making sehingga dapat menjadi rujukan literatur yang akan datang. Selain itu hasil penelitian ini juga dapat menjadi dasar bagi praktisi tentang factor - factor apa yang dapat memunculkan niat beli ulang pada masyarakat.

\section{DAFTAR PUSTAKA}

1. Ajami, M. P., Elola, L. N., \& Pastor, J. (2018). Validation and improvement of the European Customer Satisfaction Index for the Spanish wine sector. TQM Journal, $30(2)$, 133-152. https://doi.org/10.1108/TQM-07-20160056

2. Alex, D., \& Thomas, S. (2011). Impact of Product Quality , Service Quality and Contextual Experience on Customer Perceived Value and Future Buying Intentions. European Journal of Business and Management, 3(3), 307-316.

3. Anwar, S., \& Gulzar, A. (2011). Impact of perceived value on word of mouth endorsement and customer satisfaction: mediating role of repurchase intentions. International Journal of Economics ..., 1(5), 46-54.

http://www.managementjournals.org/ijem s/5/IJEMS-11-1423d.pdf

4. Asgharian, R., Salehi, M., Saleki, Z. S., Hojabri, R., \& Nikkheslat, M. (2010). Green product quality, green corporate image, green customer satisfaction, and green customer loyalty. African Journal of Business Management, 4(13), 2836-2844.

5. Bei, L. T., \& Chiao, Y. C. (2006). The 
determinants of customer loyalty: An analysis of intangibile factors in three service industries. International Journal of Commerce and Management, 16(3-4), 162177.

https://doi.org/10.1108/105692106800002 15

6. Beneke, J., Brito, A., \& Garvey, K. A. (2015). Propensity to buy private label merchandise: The contributory effects of store image, price, risk, quality and value in the cognitive stream. International Journal of Retail and Distribution Management, 43(1), 43-62. https://doi.org/10.1108/IJRDM-09-20130175

7. Beneke, J., Flynn, R., Greig, T., \& Mukaiwa, M. (2013). The influence of perceived product quality, relative price and risk on customer value and willingness to buy: A study of private label merchandise. Journal of Product and Brand Management, 22(3), 218-228. https://doi.org/10.1108/JPBM02-2013-0262

8. Chang, S. C., Chou, P. Y., \& Wen-Chien, L. (2014). Evaluation of satisfaction and repurchase intention in online food groupbuying, using Taiwan as an example. British Food Journal, 116(1), 44-61. https://doi.org/10.1108/BFJ-03-2012-0058

9. Chumpitaz, R., \& Paparoidamis, N. G. (2020). The impact of service/product performance and problem-solving on relationship satisfaction. Academia Revista Latinoamericana de Administracion, 33(1), 95-113. https://doi.org/10.1108/ARLA-112018-0266

10. Cravens, D. W. (1996) Pemasaran Strategis Edisi Keempat. Erlangga: Jakarta.

11. Curtis, T., Abratt, R., Rhoades, D., \& Dion, P. (2011). Customer Loyalty, Repurchase and Satisfaction: A Meta-Analytical Review. Journal of Consumer Satisfaction, Dissatisfaction \& Complaining Behavior, 24, 1-26.

12. Dölarslan, E. S. (2014). Assessing the effects of satisfaction and value on customer loyalty behaviors in service environments: Highspeed railway in Turkey as a case study. Management Research Review, 37(8), 706727. https://doi.org/10.1108/MRR-062013-0152
13. Gök, O., Ersoy, P., \& Börühan, G. (2019). The effect of user manual quality on customer satisfaction: the mediating effect of perceived product quality. Journal of Product and Brand Management, 28(4), 475-488. https://doi.org/10.1108/JPBM10-2018-2054

14. Han, J. W., \& Kwon, H. H. (2009). The mediating effect of perceived quality between extrinsic cues and perceived value in ski products. International Journal of Sports Marketing and Sponsorship, 10(4), 287-301. https://doi.org/10.1108/ijsms-1004-2009-b003

15. Johnson, C. J., Grimm, C. M., \& Blome, V. (2007). Customer service in the Baltic region: An exploratory analysis. The International Journal of Logistics Management, 18(2), 157-173. https://doi.org/10.1108/095740907108169 13

16. Kotler. P. \& Keller. K. L. (2009) Manajemen Pemasaran Edisi 13. Erlangga. Jakarta.

17. Lai, W. T., \& Chen, C. F. (2011). Behavioral intentions of public transit passengers-The roles of service quality, perceived value, satisfaction and involvement. Transport Policy, 18(2), 318-325. https://doi.org/10.1016/j.tranpol.2010.09. 003

18. Lee, J. W., \& Tai, S. W. (2009). Determinants of product quality perceptions and their application to marketing standardisation: The case of the automobile in Kazakhstan. International Journal of Emerging Markets, 4(2), 119-136. https://doi.org/10.1108/174688009109457 65

19. Md. Ariff, M., Hiew, S., \& Ismail, K. (2012). Relationship between customers' perceived values, satisfaction and loyalty of mobile phone users. Review of Integrative Business and Economics Research, 1(1), 126-135.

20. Ravald, A., \& Grönroos, C. (1996). The value concept and relationship marketing. European Journal of Marketing, 30(2), 1930. https://doi.org/10.1108/030905696101066 26

21. Raza, M. A., \& Siddiquei, A. N. (2012). Interdisciplinary Journal of Contemporary Research In Business Relationship Between 
Service Quality, Perceived Value, Satisfaction And Revisit Intention In Hotel Industry Service Quality Coordinator. 788805.

22. Salahuddin, M., \& Lee, Y. A. (2020). Identifying key quality features for wearable technology embedded products using the Kano model. International Journal of Clothing Science and Technology. https://doi.org/10.1108/IJCST-08-20190130

23. Sekaran. U. (2006). Reseach Methods For Business: Metodologi Penelitian untuk Bisnis. Salemba Empat: Jakarta.

24. Shih, Y. Y., \& Fang, K. (2005). Customer defections analysis: An examination of online bookstores. TQM Magazine, 17(5), 425-439.

https://doi.org/10.1108/095447805106159 33

25. Trivedi, S. K., \& Yadav, M. (2018). Predicting online repurchase intentions with e- satisfaction as mediator: a study on Gen Y. VINE Journal of Information and Knowledge Management Systems, 48(3), 427-447. https://doi.org/10.1108/VJIKMS-10-20170066

26. Vera, J. (2015). Perceived brand quality as a way to superior customer perceived value crossing by moderating effects. Journal of Product and Brand Management, 24(2), 147-156. https://doi.org/10.1108/JPBM04-2014-0551

27. Yang, Y. (2018). Is transparency a doubleedged sword in citizen satisfaction with public service? Evidence from China's public healthcare. Journal of Service Theory and Practice, 28(4), 484-506. https://doi.org/10.1108/JSTP-06-20170102 